ISSN: 1858-2664

September 2008, Vol. 4 No. 2

\title{
KEMANDIRIAN PEMBUDIDAYA IKAN PATIN DI LAHAN GAMBUT DI DESA TANGKIT BARU, KEC. KUMPE ULU, KABUPATEN MUARO JAMBI PROVINSI JAMBI
}

\author{
(SELF RELIANCE OF THE PATIN FISH FARMER IN PEATLANDS \\ IN TANGKIT BARU VILLAGE, SUBDISTRICT OF KUMPE ULU, \\ DISTRICT OF MUARO JAMBI, PROVINCE OF JAMBI)
}

\author{
Aprolita, Siti Amanah, dan Djoko Susanto
}

\begin{abstract}
Self reliance of the patin fish farmers in Tangkit Baru Village is very important to promote better quality of life. Self reliance of the fish farmers reflected ability of them in coping the problems and finding out of alternatives solution. The objectives of the study were: (1) To indentify the characteristics of patin fish farmers in peatlands, (2) To analyze self reliance of the patin fish farmers in managing of aquaculture, (3) To analyze the relationship between the self reliance of the patin fish farmers and their characteristics. Population of this study were the patin fish farmers in Tangkit Baru. The number of the respondens were 69 patin fish farmers in Tangkit Baru which were taken by simple random sample. The data were collected on May to July 2007. The data were analyzed by using Correlation Spearman. The results of the study were: (1) Cultivation of patin fish in Tangkit Baru village is very successful. The fish farmers could modify their business well, as they conducted their budiness independently, (2) Patin fish farmers have been done a good action in capital management, production process and marketing, (3) There were significant relation between self reliance of the patin fish farmers and their characteristics, namely in formal education, motivation, family dependent members, cosmopolite, man power, and experience in business.
\end{abstract}

Key words: self reliance, patin fish cultivator, peatlands, patin fish

\section{Pendahuluan}

Kemandirian pembudidaya ikan patin di desa Tangkit Baru tidak terlepas dari keinginan untuk hidup lebih baik dengan pendapatan yang semakin meningkat. Masyarakat dikatakan mandiri apabila telah dapat menolong dirinya sendiri dalam mengidentifikasi masalah dan mencari jalan keluar penyelesaiannya. Pembudidaya Ikan patin dapat dikatakan berhasil apabila mereka dapat menjaga kelangsungan usaha budidaya dengan baik, sehingga dapat membantu memperbaiki kondisi rumah tangga, usaha, dan aspek sosial kemasyarakatan.

Dalam konteks pembangunan sikap mandiri harus dijadikan tolok ukur keberhasilan, yakni apakah rakyat atau masyarakat menjadi lebih mandiri (bebas) atau malah semakin bergantung. Misalnya apakah pembudidaya ikan patin lebih bebas dalam melakukan usaha budidayanya.

Pembudidaya ikan patin di Desa Tangkit Baru memiliki keunikan dari sisi lahan usaha bila dibandingkan dengan yang ada di Jawa. Di Desa Tangkit Baru lahan 
gambut dimanfaatkan sebagai media tanaman dan ternyata pembudidaya mampu menjalankan usaha budidaya ikan patin di lahan usaha yang kritis itu.

Di Desa Tangkit Baru saat ini telah berkembang kolam ikan sebanyak 559 unit ( \pm 18 ha atau $10 \%$ dari potensi yang ada) yang dikelola oleh 230 kepala keluarga. Tingkat produksi yang dicapai saat ini adalah $1-2$ ton/unit/musim tanam untuk luas kolam antara $200-400 \mathrm{~m}^{2} /$ unit, sehingga dari kawasan ini setiap hari rata-rata dapat dihasilkan ikan patin sebanyak 2-3 ton. Saat ini kebutuhan ikan patin di pasaran Provinsi Jambi setiap hari sebesar 5 ton.

Untuk itulah penelitian ini menjadi penting dilakukan, mengingat ikan patin merupakan komoditas unggulan. Selain itu upaya pembudidaya untuk mengelola lahan gambut sebagai lokasi pembudidayaan ikan patin dapat dikembangkan di kondisi lingkungan yang serupa. Berdasarkan hal di atas, maka permasalahan yang diajukan dalam penelitian ini adalah sebagai berikut: Apa yang dilakukan pembudidaya ikan patin di lahan gambut? Faktor-faktor apa saja yang berhubungan dengan kemandirian pembudidaya ikan patin dalam mengelola usaha budidayanya? Bagaimana langkahlangkah atau upaya untuk menjamin keberlanjutan atau kemandirian pembudidaya dalam mengelola usaha budidaya ikan patin?

Kemandirian pembudidaya ikan patin dapat dilihat dari pencapaian keberhasilan dalam usaha budidaya yang berdampak langsung pada hasil budidaya yang diperoleh per masa tanam, maka tujuan dari penelitian ini adalah untuk: (1) Mengidentifikasi keragaan pengelolaan budidaya ikan patin yang dilakukan oleh pembudidaya ikan patin di lahan gambut. (2) Menganalisis kemandirian pembudidaya ikan patin dalam mengelola usaha budidayanya, yang meliputi aspek modal/keungan, produksi, dan pemasaran. (3) Mengkaji hubungan antara kemandirian pembudidaya dengan karakteristik yang dimiliki pembudidaya ikan patin.

\section{Metode Penelitian}

Populasi penelitian adalah pembudidaya ikan patin di Kecamatan Kumpe Ulu Kabupaten Muaro Jambi Provinsi Jambi. Pemilihan lokasi tersebut didasarkan pada potensi pengembangan usaha budidaya ikan patin di kolam dan karakteristik lahan yakni berupa lahan gambut dengan jenis ikan patin yang dibudidayakan adalah jenis siam. Pengumpulan data dilakukan pada bulan Mei sampai Juli 2007.

Penentuan sampel dilakukan dengan acak sederhana yakni cara pengambilan sampel dari anggota populasi dengan menggunakan acak tanpa memperhatikan strata (tingkatan) dalam anggota populasi tersebut. Pada lokasi penelitian jumlah pembudidaya ikan patin sebanyak 230 orang dengan jumlah sampel yang diambil sebanyak 69 orang pembudidaya di lokasi penelitian.

Penelitian ini dirancang sebagai
sebuah penelitian survei, di mana pengambilan data primer dilakukan melalui wawancara dan pengisian kuesioner. Penelitian ini merupakan penelitian deskriptif korelational yang mempelajari huubungan antara peubah bebas dengan terikat. Analisis hubungan antara peubah penelitian menggunakan korelasi Spearman (Nazir. 1998), dan untuk memudahkan pengolahan data digunakan program SPSS.

\section{Hasil Dan Pembahasan}

\section{Keragaan Budidaya Ikan Patin di Lahan Gambut}

Kemandirian pembudidaya ikan patin yang diamati dalam penelitian ini adalah: terdiri dari faktor internal yaitu: 1. umur, 2. motivasi, 3. pengalaman usaha, 4. tingkat pendidikan formal, 5. tanggungan keluarga, 6 . tingkat kekosmopolitan, 7. kontak dengan penyuluh, 8. tenaga kerja, 9. akses kredit, dan 10. kontak dengan penyuluh (Tabel 1). 
Tabel 1. Distribusi Pembudidaya Ikan Patin pada Sejumlah Karakteristik yang Diamati

\begin{tabular}{|c|c|c|c|c|}
\hline \multirow[t]{2}{*}{ No } & \multirow[t]{2}{*}{ Karakteristik Pembudidaya } & \multirow[t]{2}{*}{ Kategori } & \multicolumn{2}{|c|}{ Jumlah } \\
\hline & & & $\mathrm{n}$ & $\%$ \\
\hline \multirow[t]{3}{*}{1.} & Umur & Muda & 17 & 24.6 \\
\hline & & Sedang & 21 & 30.4 \\
\hline & & Tua & 31 & 44.9 \\
\hline \multirow[t]{3}{*}{2.} & Motivasi & Rendah & 17 & 24.6 \\
\hline & & Sedang & 24 & 34.8 \\
\hline & & Tinggi & 28 & 40.6 \\
\hline \multirow[t]{3}{*}{3.} & Pengalaman Usaha & Kurang & 21 & 30.4 \\
\hline & & Sedang & 22 & 31.9 \\
\hline & & Banyak & 26 & 37.7 \\
\hline \multirow[t]{3}{*}{4.} & Tingkat Pendidikan & Rendah & 20 & 29.0 \\
\hline & & Sedang & 27 & 39.1 \\
\hline & & Tinggi & 22 & 31.9 \\
\hline \multirow[t]{3}{*}{5.} & Tanggungan Keluarga & Sedikit & 20 & 29.0 \\
\hline & & Sedang & 22 & 31.9 \\
\hline & & Banyak & 27 & 39.1 \\
\hline \multirow[t]{3}{*}{6.} & Kekosmopolitan & Rendah & 24 & 34.8 \\
\hline & & Sedang & 25 & 36.2 \\
\hline & & Tinggi & 20 & 29.0 \\
\hline \multirow[t]{3}{*}{7.} & Kontak dengan Penyuluh & Kurang & 30 & 43.5 \\
\hline & & Sedang & 20 & 29.0 \\
\hline & & Sering & 19 & 27.5 \\
\hline \multirow[t]{3}{*}{8.} & Tenaga Kerja & Sedikit & 28 & 40.6 \\
\hline & & Sedang & 20 & 29.0 \\
\hline & & Banyak & 21 & 30.4 \\
\hline \multirow[t]{3}{*}{9.} & Akses Kredit & Sulit & 26 & 37.7 \\
\hline & & Sedang & 21 & 30.4 \\
\hline & & Mudah & 22 & 31.9 \\
\hline
\end{tabular}

Berdasarkan keragaan budidaya ikan patin di Desa Tangkit Baru ada beberapa hal yang menarik untuk dibahas, ini dapat dilihat pada tabel di bawah, bahwa kemandirian pembudidaya ikan patin di lokasi penelitian tidaklah tergantung pada umur, dan pendidikan, yang sangat mendukung dalam kemandirian pembudidaya ikan patin di Desa Tangkit Baru adalah motivasi untuk hidup lebih baik lagi sehingga terpenuhinya kebutuhan hidup sehari-hari. Hal ini senada dengan apa yang diungkapkan Padmowihardjo (1994) bahwa motivasi merupakan usaha yang dilakukan oleh manusia untuk menimbulkan dorongan berbuat atau melakukan tindakan yang menyebabkan seseorang berbuat sesuatu guna mencapai tujuan yang diinginkan.

Pembudidaya ikan patin memiliki banyak pengalaman sehingga mereka dapat menjalankan usaha budidaya ikan patin ini. Walaupun tingkat kekosmopolitan dan kontak dengan penyuluh rendah, tetapi pembudidaya sangat aktif dalam kelompok yang mereka dirikan. Mereka selalu mengadakan diskusi dan saling membantu apabila diperlukan atau bila menemui kesulitan dalam melakukan budidaya. Hal ini menunjukan bahwa kemandirian bukanlah tergantung kepada orang lain tetapi kemandirian akan timbul apabila terjadinya saling tolong menolong antar sesama pembudidaya ikan patin. Menurut Slamet (1995) kemandirian diarahkan agar dengan kekuatan dan kemampuannya, mereka berupaya untuk bekerjasama dalam mencapai segala yang dibutuhkan dan diinginkan. 
Kemandirian Pembudidaya dalam Usaha Budidaya Ikan Patin di Lahan Gambut

Untuk melihat tingkat kemandirian pembudidaya ikan patin maka digunakan kategori berdasarkan nilai tengah simpangan baku dari sebaran data yang diperoleh.
Kemandirian pembudidaya dalam usaha budidaya ikan patin terdiri atas: Tingkat kemandirian dalam proses budidaya ikan patin yang baik dan benar, tingkat kemandirian dalam pengelolaan modal dan keuangan, tingkat kemandirian dalam pemasaran hasil budidaya ikan patin (Tabel 2).

Tabel 2. Distribusi Responden Berdasarkan Tingkat Kemandirian dalam Budidaya Ikan Patin

\begin{tabular}{|c|c|c|c|c|}
\hline No & Peubah & Kategori & Jumlah & Persentase \\
\hline \multirow[t]{3}{*}{1.} & Tingkat kemandirian & Rendah (jumlah skor $\leq 25$ ) & 52 & 75.4 \\
\hline & dalam pengelolaan & Sedang (jumlah skor $25-30$ ) & 11 & 15.9 \\
\hline & modal & Tinggi (jumlah skor $\geq 30$ ) & 6.0 & 8.70 \\
\hline \multirow[t]{4}{*}{2.} & Tingkat kemandirian & & & \\
\hline & dalam proses budidaya & Rendah (jumlah skor $\leq 18$ ) & 1.0 & 1.50 \\
\hline & & Sedang (jumlah skor $18-23$ ) & 15 & 21.7 \\
\hline & & Tinggi (jumlah skor $\geq 23$ ) & 53 & 76.8 \\
\hline \multirow[t]{4}{*}{3.} & Tingkat kemandirian & & & \\
\hline & dalam pemasaran hasil & Rendah (jumlah skor $\leq 33$ ) & 0.5 & 0.75 \\
\hline & & Sedang (jumlah skor $33-38$ ) & 16.5 & 23.85 \\
\hline & & Tinggi (jumlah skor $\geq 38$ ) & 52 & 75.4 \\
\hline
\end{tabular}

Tingkat Kemandirian Pembudidaya Ikan Patin $\underline{\text { dalam Pengelolaan Modal }}$

Jumlah skor tingkat kemandirian responden dalam permodalan dapat dilihat pada Tabel 2. yang memberi gambaran bahwa pembudidaya memiliki tingkat kemandirian dalam permodalan rendah yakni sebanyak 52 pembudidaya memiliki skor rendah yakni kurang dari skor 25.

Dalam melakukan usaha budidaya ikan patin, responden memanfaatkan modal yang dimiliki sendiri. Modal yang didapat dari luar berupa fasilitas pinjaman dari Bank diberikan pada beberapa orang saja. Hal ini disebabkan agunan yang diberikan pembudidaya kepada Bank dianggap tidak layak atau tidak mencukupi oleh pihak Bank. Biasanya pembudidaya mengagunkan lahan usahanya.
Permodalan sesungguhnya merupakan salah satu persoalan utama yang dikeluhkan oleh responden. Selama ini pembudidaya ikan patin mengandalkan modal sendiri yang jumlahnya terbatas. Modal tersebut cukup untuk melakukan usaha budidaya ikan patin (untuk beberapa kolam) dan sisanya untuk memenuhi kebutuhan hidup, namun tidak cukup sebagai modal untuk mengembangkan usaha budidaya ikan patin yang lebih besar.

Para pembudidaya berkeinginan untuk meningkatkan hasil, selain dengan cara memperbanyak kolam, juga dapat melakukan pengolahan hasil budidaya untuk meningkatkan nilai jual. Untuk itu diperlukan modal yang tidak sedikit. Menurut Suratiyah (2006) modal adalah barang ekonomi yang dapat digunakan untuk memproduksi kembali, mempertahankan atau meningkatkan pendapatan. Sehingga modal merupakan faktor penunjang utama dalam kegiatan budidaya. Tanpa adanya modal, pembudidaya 
akan sulit mengembangkan usaha budidayanya.

Dalam melakukan usaha budidaya ikan patin, responden tidak pernah mencatat keluar masuknya uang atau pendapatan rumah tangga. Mereka tidak melakukan perencanaan usaha, apalagi melakukan analisis untung rugi usaha. Sebagian kecil mereka yang melakukan pencatatan uang masuk dan keluar dan menganalisis untung dan rugi, hal ini dilakukan oleh pembudidaya yang memiliki tingkat pendidikan yang tergolong tinggi. Keputusan-keputusan yang berkaitan dengan keuangan dan modal usaha budidaya ikan patin umumnya diambil berdasarkan kebiasaan atau informasi dari sesama pembudidaya ikan patin.

\section{$\underline{\text { Tingkat Kemandirian dalam }}$ Proses Produksi}

Jumlah skor tingkat kemandirian responden dalam proses produksi dapat dilihat pada Tabel. 2 yang memberi gambaran bahwa pembudidaya memiliki tingkat kemandirian dalam proses produksi tinggi yakni sebanyak 53 pembudidaya memiliki skor tinggi diatas 23.

Hampir seluruh responden telah mengetahui dengan baik teknik budidaya ikan patin. Pengetahuan tersebut mereka dapatkan baik melalui kelompok, media massa, dari mulut ke mulut di antara sesama pembudidaya ikan patin, atau dari pembudidaya yang menjadi panutan pembudidaya lain di lokasi penelitian.

Setiap proses produksi umumnya dilakukan sendiri oleh pembudidaya ikan patin, kecuali pada saat persiapan lahan yakni penggalian tanah yang dilakukan dengan menggunakan exavator dan pada pembudidaya yang banyak memiliki kolam mereka biasanya mengupah tenaga kerja dengan sistem bagi hasil.

Sedangkan pengairan, pembudidaya mendapatkan air dari mata air yang berasal dari kolam itu sendiri. Mata air akan didapat bila penggalian kolam kurang lebih 1 meter. Air untuk kolam ini berwarna coklat kehitaman, hal ini karena air tersebut berasal dari lahan gambut.

Pada seleksi dan penebaran benih, pembudidaya tidak melakukan penyeleksian benih karena mereka membeli benih yang telah siap tebar lewat Balai Benih Air Tawar (BBAT) Sei. Gelam dan penyedia bibit ikan patin siam perorangan yang terdapat di Provinsi Jambi. Penebaran benih dilakukan pada suhu air rendah yakni pada pagi hari atau sore hari. Biasanya benih dimasukan perlahan-lahan pada kotak-kotak kecil yang dibuat dalam kolam. Hal ini dilakukan agar benih dapat beradaptasi dengan kondisi air kolam.

Kemandirian pembudidaya ikan patin pada tahap pengelolaan pakan, biasanya pembudidaya patin mendapatkan pakan dari kelompok budidaya yang membuat pakan sendiri. Pembuatan pakan sendiri di lokasi penelitian bertujuan untuk menekan harga pakan, sehingga pembudidaya tidak begitu terbebani dengan harga pakan dalam pembudidayaan ikan patin, karena ikan patin ini terkenal sangat rakus makanan untuk membesarkan tubuhnya. Pemberian pakan dilakukan pembudidaya pada waktu pagi hari dan pada waktu sore hari.

Pada tahap pengamatan kesehatan dan penyakit pembudidaya melakukan sendiri melalui informasi yang didapat dari pembudidaya lain, buku, media massa, maupun dari pengalaman yang sudah mereka dapati selama melakukan usaha budidaya ikan patin. Pengamatan kesehatan dan penyakit berguna sekali, hal ini menurut responden agar mereka cepat tanggap dalam mengambil tindakan yang tepat pada saat ikan patin yang ada pada kolam pembesaran memperlihatkan gejala-gejala yang tidak biasanya, dan pembudidaya juga bisa mencari solusi terhadap musuh alami dalam budidaya ikan patin yakni: berang-berang, biawak, ataupun ikan gabus yang suka memakan benih patin yanng berukuran kecil.

Kemandirian pembudidaya dalam pengendalian hama dan penyakit sangat membantu dalam proses budidaya ini. Hal ini disebabkan mereka sangat paham bila terdapat 
gejala-gejala ikan patin yang terserang hama dan penyakit dan bagaimana cara pengobatannya. Disisi lain, pembudidaya ikan patin dalam pengendalian hama dan penyakit juga mendapat bantuan dari pembudidaya lain yanng lebih tahu dan paham bagaimana cara penanggulangannya. Terlihat di sini bahwa pembudidaya yang mandiri bukanlah mereka yang melakukan semua hal dengan sendiri tanpa bantuan orang lain.

Proses pengolahan ikan patin menjadi abon di lokasi penelitian masih dilakukan secara berkelompok oleh para wanita desa. Pengolahan ikan patin menjadi abon adalah salah satu usaha agar produksi yang melimpah saat ini tidak sia-sia atau terbuang pada saat panen. Pengolahan hasil ini juga meningkatkan pendapatan keluarga.

\section{Tingkat Kemandirian dalam Pemasaran Hasil}

Jumlah skor tingkat kemandirian responden dalam pemasaran hasil dapat dilihat pada Tabel 2. yang memberi gambaran bahwa pembudidaya memiliki tingkat kemandirian dalam pemasaran hasil tinggi yakni sebanyak 52 pembudidaya memiliki skor tinggi di atas skor 38 .

Kemandirian pembudidaya ikan patin dalam aspek pemasaran tergolong tinggi. Pemasaran yang dilakukan oleh pembudidaya ikan patin yakni pedagang pengumpul langsung membeli ikan patin ke pembudidaya, bila harga telah disepakati maka ikan patin pun akan dipanen dan langsung diambil pedagang pengumpul. Dari pedagang pengumpul ini akan dijual ke pasar-pasar tradisional yang ada di Provinsi Jambi. Menurut Oedjoe (2001) banyaknya saluran pemasaran akan menentukan besarnya harga komoditi yang bersangkutan.

Pemasaran ikan patin di lokasi penelitian memiliki rantai yang pendek. Pembudidaya tak perlu melakukan penjualan ke pasar induk yang ada di Jambi, tetapi pedaganglah yang menjemput hasilnya. Disini pembudidaya ikan patin dituntut kejeliannya dalam menjaring pembeli yang datang ke lokasi agar mereka mau menjadi langganan tetap. Kelemahan dari pemasaran ini menurut responden adalah bila mereka tidak pintar memperlakukan pembeli bisa saja pembeli akan mencari ikan patin ke pembudidaya lain yang dianggap dapat bekerjasama dengan baik.

Di lokasi penelitian pembudidaya sangatlah kompak dalam melakukan usahanya, karena selain mereka membudidayakan ikan patin secara perorangan mereka juga tergabung dalam kelompok usaha budidaya ikan patin. Kelompok budidaya ini mengadakan pertemuan setiap tanggal 10, untuk membahas masalah harga, pemasaran, dan hal-hal yang menyangkut usaha budidaya ikan patin.

\section{Hubungan Karakteristik Pemudidaya $\underline{\text { Ikan Patindengan Kemandirian }}$}

Hubungan antara karakteristik responden dengan kemandiriannya dalam usaha budidaya ikan patin dapat dilihat pada Tabel. 3

Umur dengan kemandirian responden dalam usaha budidaya ikan patin di lahan gambut tidak memiliki hubungan yang nyata. Dengan kata lain, bahwa umur tidak mempengaruhi kemandirian responden dalam kegiatan usaha budidaya ikan patin, baik pada aspek pengelolaan modal, proses produksi, maupun pemasaran. Pada lokasi penelitian umur pembudidaya tidaklah menjadi aspek penghalang pembudidaya dalam kemandirian usaha budidaya ikan patin. Dimana usia muda, sedang, dan tua masing-masing memiliki kemandirian yang sama dalam melakukan usaha budidaya ikan patin ini. Begitupula dengan pengelolaan modal dan pemasaran.

Tingkat pendidikan formal memiliki koefisien korelasi yang tinggi dengan tingkat kemandirian dalam modal. Hal ini berarti ada kecenderungan semakin tinggi tingkat pendidikan formal responden, maka tingkat kemandirian dalam modal semakin tinggi. Hal ini senada dengan hasil penelitian (Suyono, 
Tabel. 3 Hubungan Karakteristik Pembudidaya Ikan Patin dengan Kemandirian

\begin{tabular}{|l|l|c|c|c|}
\hline \multirow{2}{*}{ No } & Peubah & \multicolumn{3}{|c|}{ Tingkat Kemandirian Responden dalam: } \\
\cline { 3 - 5 } & & $\begin{array}{c}\text { Pengelolaan } \\
\text { Modal }\end{array}$ & Proses Produksi & Pemasaran \\
\hline 1. & Umur & -0.05 & -0.08 & 0.080 \\
\hline 2. & Pendidikan Formal & $0.352^{* *}$ & 0.199 & 0.233 \\
\hline 3. & Motivasi & -0.169 & -0.25 & -0.230 \\
\hline 4. & Jumlah Tanggungan & $0.18^{*}$ & -0.037 & 0.155 \\
\hline 5. & Keluarga & $0.363^{* *}$ & -0.05 & 0.127 \\
\hline 6. & Penmopolitan & $0.418^{* *}$ & 0.013 & 0.099 \\
\hline 7. & Tenaga Kerja & 0.146 & $0.24 *$ & 0.235 \\
\hline 8. & Kontak dengan Penyuluh & 0.051 & -0.066 & -0.230 \\
\hline 9. & Akses Kredit & $0.425^{* *}$ & 0.178 & 0.112 \\
\hline Keten & & & \\
\hline
\end{tabular}

Keterangan:

$*$ = terdapat hubungan yang nyata pada $\alpha=0.05$

$* *=$ terdapat hubungan yang nyata pada $\alpha=0.01$

2006) bagi mereka yang memiliki tingkat pendidikan yang memadai, jalan menuju keberdayaan lebih terbuka lebar ketimbang mereka yang tidak berpendidikan. Pengalaman di negara-negara maju membuktikan, bahwa manusia-manusia mandiri sebagian besar datang dari mereka yang berpendidikan cukup tinggi. Sedangkan hubungan pendidikan formal dengan proses produksi dan pemasaran tidak berhubungan dengan kemandirian pembudidaya.

Motivasi pembudidaya ikan patin tidak memiliki hubungan nyata dengan tingkat kemandirian dalam proses produksi dengan koefiesien korelasi. Ini berbeda dengan hasil penelitian Sumardjo (1999) dan Agussabti (2002) yang menyatakan bahwa besarnya motivasi berpengaruh positif terhadap tingkat kemandirian petani.

Dalam penelitian ini ditemukan bahwa pembudidaya yang memiliki motivasi yang tinggi dalam melakukan usaha budidaya ikan patin tetapi kemandiriannya dalam proses budidaya rendah. Pembudidaya memiliki keinginan yang kuat dalam melakukan usaha budidaya ikan patin sehingga mereka memiliki motivasi yang tinggi untuk meningkatkan penghasilannya dalam usaha budidaya ikan patin ini, tetapi pada dasarnya mereka belumlah mandiri dalam melakukan proses produksi, hal ini disebabkan usaha budidaya ikan patin ini merupakan usaha yang masih tergolong baru bagi mereka, sehingga pembudidaya masih banyak tergantung pada pembudidaya lain yang dianggap berhasil dalam melakukan usaha budidaya ikan patin. Hal ini menyebabkan tingkat kemandiriannya terukur rendah.

Jumlah tanggungan keluarga berkorelasi positif nyata terhadap kemandirian pembudidaya dalam permodalan untuk melakukan usaha budidaya ikan patin ini. Hal ini sangat jelas kaitannya karena pembudidaya tidak hanya mengeluarkan biaya untuk usaha ini tetapi pembudidaya juga harus mengeluarkan uang untuk mencukupi kebutuhan keluarganya baik pangan, sandang, pendidikan dan lain-lain, sehingga uang yang digunakan terbagi-bagi dalam penggunaannya. Sedangkan dalam proses produksi dan pemasaran jumlah tanggungan keluarga tidak mempengaruhi tingkat kemandirian pembudidaya.

$$
\text { Pengalaman usaha budidaya }
$$
responden berkorelasi positif nyata dengan tingkat kemandirian pembudidaya pada aspek pengelolaan modal. Dengan kata lain, bahwa pengalaman sangat mempengaruhi mereka dalam mencari modal dan menggunakan 
modal. Mereka yang memiliki banyak pengalaman cenderung berhati-hati dalam mengeluarkan uang untuk usaha budidayanya, mereka takut membelanjakan uangnya untuk modal dalam usaha budidaya ikan patin ini karena resiko kegagalan dapat saja terjadi bila tidak hati-hati dalam melakukan usaha budidaya ikan patin ini. Sedangkan pengalaman tidak mempengaruhi tingkat kemandirian pembudidaya dalam proses produksi dan pemasaran hasil.

Tingkat kekosmopolitan pembudidaya ikan patin sangat berkorelasi postif nyata dalam kemandirian pembudidaya ikan patin dalam hal permodalan. Hal ini terlihat dari modal yang diperoleh pembudidaya yang memiliki sifat kosmopolit tinggi, mereka dapat meminjam ke Bank untuk pengembangan usahanya. Sedangkan pembudidaya yang tidak memiliki sifat kosmopolit mereka menggunakan modal sendiri sehingga sulit dalam mengembangkan usaha budidaya ikan patin ini. Di lokasi penelitian mereka yang memiliki sifat kosmopolit ini hanya beberapa orang saja, mereka adalah pembudidaya-pembudidaya yang tangguh dalam melakukan usahanya. Kekosmopolitan pembudidaya tidaklah memiliki pengaruh terhadap kemandirian pembudidaya pada aspek produksi dan pemasaran.

Kontak dengan penyuluh tidaklah memiliki korelasi positif nyata pada kemandirian pembudidaya ikan patin baik kemandirian dalam modal, proses produksi, maupun pemasaran. Keadaan yang terjadi di lokasi penelitian adalah penyuluh belum memegang peranan penting dalam mendukung usaha budidaya ikan patin ini, tetapi pemudidaya sendirilah yang sangat kuat keinginannya untuk meningkatkan penghasilannya dengan melakukan usaha budidaya ikan patin.

Penggunaan tenaga kerja dalam usaha budidaya ikan patin ini berkorelasi positif nyata pada kemandirian pembudidaya pada aspek produksi. Pembudidaya yang menggunakan banyak tenaga kerja dalam usaha budidayanya semakin terbantu pada proses produksi sehingga tugas pembudidaya dengan banyaknya tenaga kerja dapat mengurangi tugas pembudidaya sehingga pembudidaya dapat melakukan aktifitas lain yang menunjang keberhasilan usaha ini seperti: mencari alternatif-alternatif lain dalam memecahkan masalah yang sedang dihadapi dalam budidaya atau mengadakan kontak dengan pihak lain.

Akses kredit pembudidaya berkorelasi positif nyata dengan tingkat kemandirian pembudidaya pada aspek pengelolaan modal dan keuangan. Di lokasi penelitian pembudidaya yang mendapatkan akses kredit lebih baik dalam pengelolaan modal dan keuangan, hal ini disebabkan mereka menyadari bahwa modal yang digunakan dalam melakukan usaha budidaya ikan patin ini bukan milik pribadi sehingga perlu pengelolaan keuangan yang benar agar uang pinjaman tersebut dapat dikembalikan setiap bulannya.

\section{$\underline{\text { Kesimpulan }}$}

Berdasarkan hasil penelitian dan pembahasan dapat dikemukakan kesimpulan sebagai berikut:

1. Keragaan pengelolaan budidaya ikan patin adalah sebagai berikut:

- Tidak tergantung pada lahan usaha

- Dapat mengelola lahan gambut menjadi produktif secara mandiri

- Pengembangan usaha secara lebih berkelanjutan

- Saling bekerjasama dalam melakukan usaha budidaya ikan patin

2. Kemandirian Pembudidaya ikan patin dalam melakukan usaha budidayanya meliputi aspek :

- Modal: memiliki tingkat kemandirian yang rendah, hal ini disebabkan modal yang digunakan adalah modal sendiri, sebagian kecil mereka yang mendapat pinjaman dari Bank.

- Proses produksi: tingkat kemandirian pembudidaya dalam proses produksi masuk dalam kategori tinggi. 
- Pemasaran: Tingkat kemandirian pembudidaya ikan patin dalam pemasaran hasil dikategorikan tinggi, pemasaran ikan patin di lokasi penelitian memiliki rantai yang pendek, pembeli langsung datang ke lokasi.

3. Dari seluruh faktor yang diteliti tampak bahwa pendidikan formal, jumlah tanggungan keluarga, kekosmopolitan, pengalaman usaha, akses kredit, tenaga kerja memiliki hubungan positif yang nyata dengan kemandirian dalam mengelola usaha.

\section{Daftar Pustaka}

Agussabti. 2002. Kemandirian Petani dalam Pengambilan Keputusan Adopsi Inovasi (Kasus Petani Sayuran di Propinsi Jawa Barat) (disertasi). Bogor: Program Pascasarjana: Institut Pertanian Bogor.

Haryono Suyono. 2006. Pemberdayaan Masyarakat (Mengantar Manusia Mandiri, Demokratis dan Berbudaya). Jakarta: Khanata.

Ken Suratiyah. 2006. Ilmu Usaha Tani. Jakarta: Penebar Swadaya.
Nazir M. 1998. Metode Penelitian. Bandung: Ghalia Indonesia.

Padmowihardjo, S. 1994. Psikologi Belajar Mengajar. Jakarta: Universitas Terbuka.

Slamet. M. 1995. Memantapkan Posisi dan Meningkatkan Peran Penyuluhan Pembangunan dalam Membangun. Disampaikan dalam Seminar Nasional Pemberdayaan Sumber Daya Manusia Menuju Terwujudnya Masyarakat Madani. Bogor.

Sumardjo. 1999. Transformasi Model Penyuluhan Pertanian Menuju Pengembangan Kemandirian Petani (disertasi). Bogor: Program Pascasarjana, Institut Pertanian Bogor. 